\title{
24. Organization Takes the Spoils: The Election in Yangoru-Saussia
}

\author{
Leo Yat Paol and Patrick Gesch
}

Those writing for the newspapers do not understand the realities of village elections. You can't win without komiti and they need a reward. It is hard work (Peter Waranaka, Hwarapia, 29 May 2007).

The above words of the governor of the East Sepik Province were programmatic for his election campaign in the Yangoru-Saussia electorate in the 2007 election. He had his komiti; they got their rewards; it was definitely hard work, and quite expensive, for him to satisfy the demands of the village voters. The outcome for the governor was a contentious return to the national parliament. In April 2008 a petition by the losing candidate, who accused the governor of bribing voters during the campaign, was upheld; however, Waranaka appealed the decision and in March 2009 was reinstated (see below). The question remains: did Waranaka in 2007 accurately describe the realities of village campaigning? Is there any other way to come out on top in national elections?

The Yangoru-Saussia electorate lies along the south side of the coastal mountain range leading north of Wewak. The mountains are as densely populated as any area in Papua New Guinea, giving the resulting settlement pattern of hamlets dispersed throughout the bush with few major gathering centres in villages. The terrain is continuously mountainous and flat areas are found only in the less-populated kunai grass plains leading down to the Sepik River. There are four local-level government (LLG) areas: Numbo, Sausso, East Yangoru and West Yangoru (Figure 24.1). The returning officer for Yangoru-Saussia was recruited from the public service in Yangoru, and the four assisting returning officers were based in the LLG offices.

For the 2002 elections, East Sepik Province had 193,276 voters according to estimates based on the 2000 national census, but there were 286,716 names on the 2002 electoral roll. ${ }^{1}$ The new electoral roll for the 2007 elections had 237,070 voters, of whom 37,020 were enrolled for Yangoru-Saussia. The total number of votes cast in Yangoru-Saussia in 2007 was 26,332-71 percent of those enrolled. The electorate does not cover a big area, and although the roads are in poor condition, it was possible to cover most centres with the use of a four-wheeldrive Suzuki. The bitumen road through the middle of the electorate, the

1 John Nonggorr, 'Challenges of the electoral roll', Post-Courier 27 March 2007, p. 12. 
common language in about 80 percent of the electorate, and the nearness of this area to the urban centre of Wewak all go to make for an electorate which can be considered quite manageable by Papua New Guinea standards.

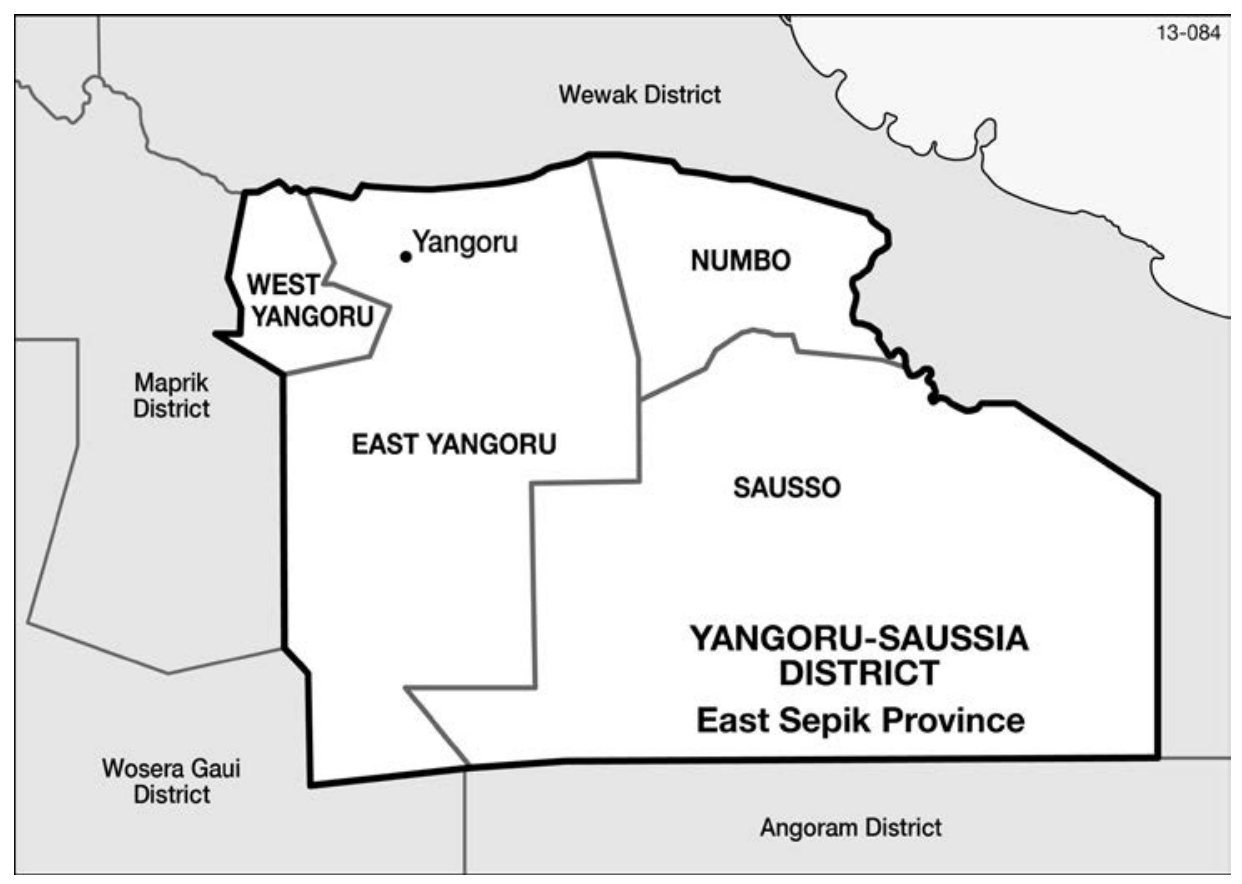

Figure 24.1: Yangoru-Saussia District

Fifteen candidates contested the Yangoru-Saussia seat in 2007, six of whom had contested a by-election for the seat in 2004 after the sitting member, Bernard Hagoria, had been found guilty of misusing public funds and dismissed from the national parliament. The candidates included three former members of parliament (Gabriel Dusava, Hagoria and John Jaminan) as well as the sitting member, Waranaka.

The Yangoru-Saussia election was full of compromises with what might be thought of as legally free and fair elections. Is this simply the reality of applying universalizing systems to the separate universes of the Papua New Guinea rural village? Some people say that we have come a long way from a concern whether we are applying the Westminster system to Papua New Guinea, the land of a thousand villages. ${ }^{2}$ How could it be otherwise? How much compromise should be institutionalized now to be able to shepherd future electoral developments along the ways of freedom and fairness?

2 'PNG presents not as a state struggling to adjust "tradition" to "alien concepts", but as a developing country adapting to its own governance, by its people, for its people. The issues are no longer (if ever they were) about whether 'Westminster democracy' was an appropriate import, but about how Papua New Guineans are building their own relationships between each other, and especially between citizen and authority. Whilst each place, province, electorate has its own pace in that process, the stories follow the same themes. Elections, in other words, are now part of the culture in $\mathrm{PNG}^{\prime}$ (Institute of Policy Studies et al. 2004, Sec. 8, p. 30). 
In what follows we will consider five issues that emerged from our observation of the election in Yangoru-Saussia.

Perhaps the most disturbing aspect of the election was the use of gifts, giving and demanding. The question arises: when was it just the social tradition, as claimed, and when did it constitute undue influence?

The Papua New Guinea Electoral Commission (PNGEC) clearly had difficulties in getting an electoral roll prepared on time and catering for all the needs of the electoral process. Allowances for officials seemed to become a bottomless source of expectations.

Voter behaviour was another cause for concern, with brawling, under-age voting, and no scope given for secret balloting.

With few exceptions political parties were used as labels to help the legitimacy of candidates but with little commitment to policies. Few parties formed lasting alliances. In this atmosphere parties barely disguised the independent stand of so many candidates. Although general approval was expressed for the new limited preferential voting system, it was not used to any effect in YangoruSaussia, where effort was spent more to void the power of preferences than to employ them.

The counting of the Yangoru-Saussia votes involved a great waste of time, taking about four full working days in a 14-day working period to produce a result from only 27,000 votes. This dispute-ridden process was barely kept on the rails, and some major clarification of the role of candidates' scrutineers is needed.

\section{Voting inducements}

Yangoru has seldom seen a festival like the nomination of Governor Peter Wararu Waranaka ${ }^{3}$ on 9 May 2007. A solid stage had been built on the old airstrip and the district administration building was decorated with an assortment of flowers and palms inside and out. The returning officer and his assistants were ready for the arrival of the dignitaries. Although the candidate Patrick Harricknen was also nominating at Yangoru on this the last day of nominations, his singsing group was soon swallowed up by the groups coming in to support the National Alliance. A number of police cars arrived from Angoram with Arthur Somare and Grand Chief Sir Michael Somare and his wife Veronica, and about 25 auxiliary police from Angoram. They accompanied the governor to the

3 We are told Wararu is Peter's personal name, while Waranaka is a name taken from his forefathers. The change for the new election did not seem troublesome to anyone. 
stand for speeches, where he acknowledged the epithet 'Minister for Transport and Funeral Services' because he had given as many as 25 expensive cars to various agencies in Yangoru, and had always made generous contributions to families when their loved ones had died. We recognised among the thousands congregated on the airstrip, people who had walked more than three hours from the Numbo side and five hours from the kunai plains for the day's celebrations. Peter Waranaka nominated, and Arthur Somare gave a data-filled election speech for National Alliance before Sir Michael departed by the waiting helicopter. There was no doubting where the strength lay on nomination day.

A few days after the nomination celebration, there followed a bizarre incident on the Sepik Highway. On 12 May Waranaka became involved in car smashing and insult hurling incidents between Passam and Munji on the Sepik Highway when his relative, senior reporter for the National newspaper, Yehiura Hriehwazi, was challenging Waranaka's secretary and other relative, Joe Kiliawi, with electoral questions and corruption charges (Post-Courier 18 May 2007, p. 6). One of Hriehwazi's group ended up seriously injured in hospital. However, the maternal kin (wawenku) of Waranaka were outraged on Waranaka's behalf, ${ }^{4}$ and made a customary presentation to him of two pigs, said to be worth K1200 and K1500. Waranaka was obliged to return double the cost to his uncles with food and beer above that. K40,000 was demanded from Hriehwazi's group to pay for the car damage. This event was exploited for all its potential as a campaign event for the next couple of weeks, as part of the 'taim bilong fri kaikai' (time for eating free, a widely acknowledged term for the election period).

There were general complaints from the supporters of other candidates that Waranaka was distributing money and 5000 mobile telephones as part of his early campaign. When he took delivery of his election posters on 29 May, a large crowd gathered at his home hamlet in Hwarapia Village. Waranaka arrived very much stressed from Wewak, and declared that there would be no campaigning that day, as it was simply a day to get the list of komiti correct, and to distribute the candidate posters. Five men and women komiti from every village in the Yangoru neighbourhood then approached the table together with other witnesses from their village in order to ascertain that the typed list was correct. Beside every name on the computer list, there was the amount K100 in the next column. Waranaka announced that part of this money was to complete the payment due from the previous election for which only K20 per person had been paid to this date. The rest was for tea night gatherings and as reward for the task of 'guarding the poster' in the villages. There was intent to pay

4 An explanatory example goes like this: a man cut off the tip of his finger in the garden and his mother's brother was there to see the accident. The injured man paid his uncle K50 because it was his mother's blood that had been spilled. Although it sounds like adding insult to injury, this is all part of the lifelong significance of the mother's brideprice, as was Waranaka's visible social injury. The mother's brothers always give food, and the sister's son always returns money or valuables. 
more when it became possible. Also as part of his public statement Waranaka expressed his disappointment that people were distorting his intentions about giving out the 5000 mobile telephones. This was being done because he was the local member; the new relay broadcast tower had just been completed on the top of nearby Mount Turu, and Michael Somare had urged him to roll out the service utilization that would make the facility active. It was a distortion to call this voter inducement. The fact that the road past Waranaka's hamlet was being graded all that day by a newly acquired second-hand grader did not get a mention.

Then followed the distribution of money, K100 each to five komiti per village from all of the Yangoru villages. I asked Waranaka whether this meant that we had K13,000 with us in the village at this moment. He agreed, and said that a similar amount had been distributed in Wewak earlier this morning to the Numbo and Sausso people.

A reliable witness informed me two weeks later that their village in the Wilaru area had received K5000 from the National Alliance campaigners during this same period. A young man saw his mother holding K100 and told her as she hid the money, 'Oh mama, em i braibim yu nau'. There were persistent stories that Waranaka's campaigners would visit villages such as Sima, Kworabri and Malimbanja the night before the polling took place and give money. One Dusava supporter said that an old lady in Malimbanja sat looking at her K10. She had wanted to vote for Dusava but now felt she was compelled to vote for Waranaka.

This then, would seem to be the substance of what Waranaka meant by the realities of village campaigning. During polling time, it was understood that he had ceased the distribution of mobile phones, because the gift was being misinterpreted as voting inducement. He continued to be dogged by violence during the campaign period. One of his electoral cars ran off the road resulting in the deaths of four men. A young man in his hamlet committed an apparent suicide. This was all put down to sanguma attacks that a bigman must suffer together with his people. A family member told me, 'In Church we are always being urged to pray for a good leader. Now one is given to us, and no one recognises him'.

Waranaka was not the only candidate to spend money on the campaign. David Nelson told us that he would reimburse coffee nights by his supporters, often in excess of K100 each time. He was also seeking to give villagers a source of income and for this he distributed black polythene bags together with cocoa seedlings to promote their self-reliance. He estimated that this venture cost him about half a million kina at election time. 
It seemed a matter of necessity that candidates provide food at their rallies. This action was usually in the hands of their supporters, and we do not know how many of these supporters were later reimbursed by the candidates. Greg Maisen, the New Generation Party's Provincial candidate, threw a large final rally for his party, including Godfrey Raushem of Yangoru-Saussia, where many pigs and much food were distributed; other candidates, too, could count a few pigs that they had funded. A number of candidates refused to do any large-scale feeding of supporters, saying they could not afford it, although plates of food would be supplied at their homes. Former long-term member of parliament John Jaminan solved the problem of fri kaikai by keeping always on the move. He would walk alone the back roads of Yangoru and through Wewak, with only a loud hailer over his shoulder, and proclaim his message to whoever might listen.

Waranaka was not the only candidate who claimed to have a komiti system. Vitus Wafi was confident that his delegates were active throughout the Numpo and Sausso LLG areas, but in fact his votes were limited to his home area. David Nelson made similar claims about his organization, but received votes only from his broader home area. The two leading candidates, Waranaka and Dusava, were the only ones to score evenly across the entire electorate, and were the only ones likely to have had a truly effective village campaign structure.

How are we to evaluate the bestowal of gifts during the election period against the proposal that there is a culture of gifts and reciprocity in Papua New Guinea, which is all but impossible to avoid? Yangoru-Saussia is an area with a long history of cargo cults (Gesch 1985:115-126) in which the material element of social interchange was a key to the hermeneutic of the meeting of cultures that was involved: 'If you love me, then give me something to show it'. But of course the gift entails a return obligation and this is understood in a simple way without any feeling of cunning or deceit. A Gaikorobi man explained this to me during election time: 'If a big man gives me a kakaruk for no reason, I wait to hear what he wants from me'. More explicitly, another Sepik man explained: 'Olsem kalsa bilong mipela stret: man i givim yu kakaruk, bai yu mas bihainim dispela kakaruk stret na givim vot long dispela man, no ken givim long narapela man' ('If someone gives you a chicken you must do what the chicken leads you to, you must give your vote to this man and no other'). The problem becomes, how to shake your hands free of the gift or erase the record, which is easier for an individual than for a community.

A Madang statement on this is: 'Gifts were and are exchanged and/or reciprocated in order to maintain, enhance, mend, or initiate relationships. The kind of gifts offered/exchanged would include food and cultural valuables. Kinship ties, tribal and clan alliances, and trade partnerships were and still are the network through which gifts were exchanged. Tribal survival, continuity and security were three significant purposes for such exchanges'. In the light of 
this thinking, voter inducements are more than just the buying of votes. They imply patronage of the bigman and his group. The candidate has to maintain the solidarity of his own group and they must relate to others as larger groupings within villages. The elected member is in a relationship to the voters, and is not just a representative in a technical sense.

\section{Electoral Commission difficulties}

Although it was impressive that the PNGEC was able to respond to recommendations for radical changes, the resulting difficulties with untested procedures occurred on all sides. It was a marvel that the PNGEC could simply decide to abandon the previous common roll and draw up a new electoral roll for the whole country. The farcical statistics for the Chimbu by-election in 2004 made such action the only reasonable way to go. In that election, best estimates from the 2000 census put the voting population in Chimbu at 170,425 but the enrolled voters numbered 451,775-almost triple the real number; it was almost impossible to make sense of polling results tainted by such fraud and deception.

The change in the form of ballot papers also seemed an incredible move at such short notice. The reasoning was convincing: how do illiterate voters make sense of a ballot paper for Wewak Open, say, with 43 photos of people they have never seen before and then assign three preferences among these 43 candidates. How much extra handling would be necessary with such papers? However, the idea that an electorate with many illiterate people could be counted on to write numbers or names on the new shorter ballot papers seemed incredible. These mandated changes worked somehow, but with many of the difficulties that could be expected to occur.

We took delivery of an East Sepik Province electoral roll on CD (costing K150 for some unknown reason), which yielded 237,070 names. We obtained this in Port Moresby only 10 days before polling was due to commence and were able to print off the enrolment lists for three villages, from Numbo, Sausso, and East Yangoru. The villagers who checked these lists found them largely reliable, with only three or four dead people still on the list and as many again known to be underage. The remote village of Komotogu, included in the Kiniambu village list, had more than a dozen names declared to be dead, but with such an out-of-the-way place, there was no reason to consider deception lay behind this. Hwarapia roll recorded one person twice - the governor, as Waranaka and Wararu, but electoral officials told us, 'It's OK. We know his face'. Spot checking other electorates gave the impression that there were a lot of double 
names recorded - two names from the same place, with the same occupation and about the same age; but this appeared to be over-reporting by the PNGEC rather than intentional deceit.

The new electoral roll came too late for any but the most astute to be able to view a copy before the elections. In Baimuru village, the councillor held up voting for hours at the start of the day's polling because he had found six names missing from the village roll. He said he had previously pursued this with the returning officer on earlier drafts of the roll and had been told it would be fixed up. But in the final copy it was not fixed. It turned out that there was a story behind these six people: they were connected with the Finance Department investigation in the East Sepik Province, and the leader of the group says his name was kept off the roll by the returning officer because this leader had exposed systemic misdirection of funds by the leaders of the province.

Other domestic observers in our group were present in villages where the electoral roll was hotly disputed. The villagers felt the problems could have been overcome if a member of the village had been in the recording team: spelling was misleading and married women were recorded in place of birth as well as place of marriage.

In the event the ballot papers arrived in the nearest LLG office, Tangori, on 30 June when polling should have been starting. In the presence of police and many bystanders, the ballots were sent out to the other LLG. In Yangoru the ballot papers were distributed the next day, Sunday, in cellophane packed bundles. There was a story going around that the voting could not begin on Saturday because the Seventh-day Adventist church could not participate on that day, but the actual situation was that the papers were late. It was at Tangori on 30 June, also, that the electoral roll appeared in hard copy for the first time. At Tangori a couple of days earlier, we had seen the first real candidate posters on the door of the LLG.

Other delays were also laid at the feet of the PNGEC. The returning officer said it was not possible to do voter education much before June because he was expecting money from the provincial electoral office. The provincial election manager denied that any such money was needed. It was said that YangoruSaussia people were already familiar with limited preferential voting through the 2004 by-election, though in fact they had not seen the new ballot papers, and few could follow the counting and elimination rules. Counting of ballots was also delayed because no trainers of electoral officials had come to Wewak five days after voting had finished. There was also doubt about the venue for counting votes, with no arrangements for telephones, security and power in 
firm place. However, the failure of these arrangements was attributed to the Provincial Steering Committee, who, in hotly debated scenes in the Wewak Electoral Office, were told that they had no legal status.

\section{Voter behaviour}

The voting period in Yangoru-Saussia was marked by a certain amount of problematic behaviour, but only once did this go so far as the safeguarding/ hijacking of a ballot box. There was frequent fighting, under-age voting, wagering on the results, and an almost complete lack of secret voting. In response to questionnaires, voters said that they had received education about HIV/AIDS but could not see any relevance to the voting process, and none was evident to us.

At Baimuru the National Alliance supporters were accused of having voted in Wewak before coming home to the village. This turned into a punch-up for a while, with the auxiliary police ignoring the fight and forming a ring around the ballot boxes. Voting was resumed. The day ended with the smashing of a truck window, which was said to be an internal dispute of the Waranaka camp.

Under-age voting was visible and in Kworabri our observers counted 42 school boys and girls blatantly casting votes. Few people seemed to be disturbed at this matter; as one father said of his daughter, 'It is not her fault that her name is on the electoral roll, and besides, she is only abiding by the Constitution in casting her vote, given that her name is on the roll'. One 14-year-old we observed barely touched his ballot paper as a guardian took it from his hands, filled it in and deposited it in the ballot box before sending the boy away. In other places boys were sent forward when the names of the dead or the absent were called. Occasionally some under-age would-be voters were stopped by the electoral officials and sent away.

There were a few cases of people caught out double voting. One woman we observed seemed genuinely confused whether she could vote at home as well as in her marital village, since her name was called again the second day. Another was caught removing the indelible ink from her finger with what was termed 'PNG lime' (probably Citrus acida). ${ }^{5}$ In Gwinyingi two voters were observed

5 Ron May put this to the test and could not see that the indelible ink was being removed (personal communication, Port Moresby 11 April 2008). This evidence is not likely to affect the widespread belief that lime juice takes the mark away. My own experiment was inconclusive: within 15 minutes of being inked and resorting to lemon juice and soap scouring, I could wash most of the ink away from my white skin; however, eight hours later it was visible. 
being allowed to vote although their names were not on the electoral roll, because the councillor identified the people as genuine villagers and the polling officer allowed them to go ahead.

The biggest loss in the voting process was in relation to secret balloting. Although it was possible for strong young men and women to go directly and vote alone, almost everybody consented to a 'witness'. This term was chosen in preference to 'helper'. In one village the witness was a young pastor who was summoned by name by many voters. In other villages the witness was a party official who was there to bear witness to the party that this voter had done what he or she promised. The end result in Kwahwie was lists of voters' names we saw who were known with certainty to have voted for the National Alliance, and would therefore share in the benefits that were to come. In Boem Sara two village men stood one meter behind the voters all day long, but in other villages either police or electoral officials were hovering over the booths the whole day. The motives seem to have been: to be sure who the party member voted for; to help illiterates; to make sure other villagers were clear on what to do; and just generally, to see what anybody was doing. No more that 5 percent of citizens voted alone. Some women expressed their resentment at this afterwards.

Even with all of this assistance, 44 Open ballots were put into Provincial boxes. But the total number of informal ballots was only 74 for the whole electoratesurely a very positive result. The Open and Provincial ballots were much too similar to each other. One was lightly printed pink and the other lightly printed blue. The ballot boxes were similar, and it is a wonder that a lot more cross balloting did not take place.

Despite regular newspaper advertisements listing electoral offences from the Organic Law on National and Local-level Government Elections Part XVII, in which the penalty for wagering on an election result was set at $\mathrm{K} 400,{ }^{6}$ the laying of bets played a role in Yangoru-Saussia voting. Immediately voting ceased at Suandogum a bystander raised some hundreds of kina and asked, 'Who will hold our bet?' The police told him to go away. In Kworabri the issue became more dramatic. Voting ended with the cry, 'Let's bet'. The National Alliance people quickly found K1000 and asked the Dusava people to meet that bet. As dusk fell in Yangoru two tightly knit chanting groups with loud slaps on the earth went past bringing a total of K1200 each to a local storekeeper, and to the police to hold as witnesses to the wager.

6 See, for example, The National, 26 June 2007, p. 10. 


\section{Political parties}

There is not a whole lot to be said about political parties in the Yangoru-Saussia election. Twelve of the 15 candidates were listed as having party endorsement, but parties were only as strong as the candidates themselves, apart from the National Alliance. Gabriel Dusava was a leading candidate, but appeared initially in the official biodata as an independent. Towards the end of the campaign period the PNGEC clarified that he had enrolled as a People's National Congress candidate, although this name did not appear on his poster. Another candidate said he had tried one party only to be put off by corruption issues, while his second attempt collapsed because promised millions from overseas were not forthcoming, and his final choice of party yielded none of the election posters he had been expecting from them.

Among the few candidates to feature their party allegiance was Godfrey Raushem of the New Generation Party. But even Raushem wryly admitted, while on the stage of the final New Generation rally of Provincial candidate, Greg Maisen, that Maisen could barely afford to be seen on the same platform as Raushem because of continuing charges made of Raushem by rumour that he was either convicted for stealing money, or was escaping bail from a court case-all of which he explicitly denied. Patrick Harricknen stood for the People's Freedom Party and campaigned with fellow lawyer and People's Freedom Party leader Moses Murray, a candidate in the Provincial contest.

Much on people's minds was the history of failed elections and lengthy court challenges in Yangoru-Saussia. Everyone was unanimous: 'We don't want another by-election'. Starting in 1972 Mathias Yaliwan had lost his seat when he found that the House of Assembly was unwilling to acknowledge his essentially God-given mandate as one-person 'Gavman' of Papua New Guinea, and failed to attend parliamentary sittings, thus forfeiting his 83 percent polling majority (see Winnett and May 1983). His lacklustre deputy, Linus Hepau, replaced him in a by-election. In 1987 John Jaminan, the sitting member since 1977, was dismissed from parliament when convicted of a rape charge and sent to prison. He was later pardoned and returned in the 1992 election. In 2000 Gabriel Dusava lost his seat on a recount of the 1997 votes, and Bernard Hagoria was sworn in without a by-election. ${ }^{7}$ Dusava's conviction in 1996 of misuse of funds while Secretary for Foreign Affairs was finally confirmed by the courts in 2000 (Geno 2005: Annexure 4, p. 3). Hagoria himself was dismissed in 2003 for mishandling of funds and Peter Wararu Waranaka won the by-election in 2004 (ibid. p. 4).

A number of candidates (Raushem, Dusava, Hagoria) faced as first comment in their campaign rallies the question, 'If you win, will the Ombudsman

7 http://www.paclii.org/pg/cases/PGLT/2003/1.html 
Commission hold you?'. Hagoria had a letter of clearance from the Ombudsman Commission on the basis of the lapse of three years since conviction. However, unfairly, when the commission wrote at the end of the letter that it was unable to comment on any other challenge or charges, villagers took this as a sign that there were indeed hidden charges. Waranaka also said that his method of campaigning had been challenged in the Wewak local courts, and he had been cleared. Two candidates (Jaminan and Parapi) walking along to Waranaka's big poster event commented, 'Yes, about 75 percent of us stand to be challenged by the Ombudsman Commission if we win'.

\section{Counting the votes}

The delay from a Saturday to a Monday in starting the polling affected three out of the four LLG areas adversely. The assistant returning officers from the three areas decided to skip the most distant places, which had been listed first for voting, and to go ahead with the schedule as planned for the remaining days. There were 19 polling teams with one Open and one Provincial ballot box each, meant to cover five or six polling places (which embraced from one to four villages or centres each) in as many days. That meant that the most distant places had to be handled last and in isolation using helicopters to minimize the long and difficult trips out and back. This left some uncertainty about the return of ballot boxes into the following week. Probably one of the distinctive features of East Sepik balloting was that all polling teams were accompanied by sets of six or so police, made up of regular, reserve and auxiliary police. These also had to be moved out to the bush. Auxiliary police have become so significant in East Sepik Province that 300 of them were sent to the Highlands to help elections up there.

Nevertheless it was announced that all the ballot boxes would be taken from Yangoru to Wewak in a grand public procession for counting on the last allowable day of polling. In fact they were delivered a couple of days earlier in a manner that alarmed many candidates.

As mentioned earlier, the Provincial Steering Committee was in charge of making arrangements for the counting of votes in Wewak. When there was a change of venue from the army barracks at Moem to the golf course, an angry crowd challenged the committee at the electoral office. The provincial administrator reversed the decision, but still some days had to be spent on the training of those counting the votes and general preparation of the counting venue. It was generally acknowledged that security was better at Moem, and the army imposed their own rules as well as those of the police. At this stage the provincial election manager was very hard to find. The story was that serious 
threats had been made against him and he had retired to his home village on Kairiru Island. The Yangoru-Saussia returning officer scorned that idea, saying that he also had received threats on his life, and the election manager was just being lazy.

Once started, the counting of votes went rapidly: informal votes were identified and votes meant for the Provincial box were taken out. Checking for the signature of the polling officer was done thoroughly. However, after the boxes were opened and ballot papers were distributed by the officials to the 15 candidate trays, very little further checking of the ballot papers was done. As officials counted the number of ballots that had been put in the tray under their supervision, they often counted while looking at the reverse side only, and no scrutineers asked to see the face of the ballots. We saw one first preference marked '[1] Peter' which lay unquestioned in Peter Waranaka's box. Only Waranaka's scrutineers were looking at that tray. We wanted to question whether votes marked [22] were going into box [23] but it all went too quickly to question.

Scrutineers told us throughout the voting process that they had full control. Voting and counting could only begin and go ahead when they decided so. The electoral officials clearly thought otherwise and sought to manage the scrutineers as best they could. Scrutineers began making loud complaints on the third day of counting, taking up a complaint from the Provincial counting at Kaindi, in Wewak town. They said they had numbers from the field for votes in boxes which differed by 178 and 222 from the total number of votes that had been counted from specified boxes on the previous days. They also claimed that the number of ballots in Open boxes in Moem and in parallel Provincial boxes in Kaindi were different, which indicated tampering with a number of votes. The returning officer disallowed all these objections, telling us that the total number of ballots used on any voting day had to be kept secret; there was no way anyone could know the total number of ballots that ought to be in a box. An electoral official in Kaindi apparently did not know about this secrecy rule, and was announcing the total number of votes in ballot boxes. One scrutineer making a loud fuss admitted that he did not understand, but needed to be seen to be making a statement on behalf of his candidate.

A bottleneck occurred in the counting when all the Open boxes had been counted, and a number of misplaced Provincial votes were on hand. Clearly an equivalent number of Open votes could be expected to be in the Provincial boxes, but the voting was going much slower in Kaindi. Everyone was dismissed for a number of days until the 44 Open ballots were brought along. Then the primary vote could be completed, and the elimination rounds begin. These were completed in a day and a half. 
In the event, Waranaka was the declared winner with 8633 votes, ahead of Dusava on 7916. Harriknen (4752) came in third, Raushem (4087) fourth, and Hagoria (3490) fifth. Jaminan (923) was a distant eighth.

\section{Conclusion}

Our judgement is that the Yangoru-Saussia election was for the larger part free and fair. Concerns must be voiced about a verifiable electoral roll, prepared in time; about the demise of the secret ballot; and most of all about the distribution of voter inducements. However, the electoral officials were sufficiently neutral and business-like to ensure that the process could go ahead as planned. The police presence was convincing enough to allow the presiding officers to take charge of the village voting, and there were always many people on hand to be sure that the transfer of votes and boxes proceeded in an orderly manner. A speeding Landcruiser on the river road to Yangoru with all lights flashing convinced us to clear the way before the transfer of votes at the end of the day. We were welcomed as domestic observers and given a good reception by all candidates. Given the good number of talented candidates, concerned about the welfare of Papua New Guinea and their electorate, the first part of the political legitimization process went well.

The winning candidate received 32.8 percent of the votes cast, which is 23.3 percent of enrolled voters in Yangoru-Saussia. ${ }^{8}$ He got 2128 of his final votes from preferences, which was 123 fewer preference votes than the runner-up, who received 30.0 percent of votes cast. Clearly preferences had little influence on this election. The woman candidate who had been assured that she had many preference votes waiting for her in the 2004 by-election was eliminated in fifth place, by which time she had gained only 20 preference votes. The winner gained votes from all over the electorate apart from Bernard Hagoria's base. It seems no one understood better than he how to organize the village vote.

\section{Postscript}

At the end of March 2008 the National Court in Wewak started hearing an election petition filed against Waranaka by Gabriel Dusava (The National 28 March 2008, p. 5). Five instances of bribery were alleged: K2000 presentation to Oscar Manihau for an auxiliary police station opening; K3800 to Alois Maniura of Soli

8 These results can be compared with the results from the by-election in 2004 where Wararu gained 4524 primary votes (19.0 percent of the votes cast) and won the election after preferences with 7073 votes (51.2 percent of the votes cast) with Dusava trailing by much the same margin as in 2007 (www.pngec.gov.pg accessed February 2007). 
Warahembe; K50 to Markus Paringu of Wamaiang village; another K50 plus an election poster to Noah Kukune of Niakandogum, and promise made to deposit K5000 into a passbook account of a women's group of Niakandogum village (The National 4 April 2008, p. 7).

Waranaka's defence was that these people were his supporters and voted for him, therefore they could not be said to have been bribed. He said that 'all monies given out were approved by the joint district planning and budget priority committee and that he had nothing to hide' (The National 31 March 2008 , p. 4). It was the third of these charges which was sustained. The outcome of the court case was proclaimed on the front page of both daily newspapers: 'K50 bribe costs MP Parlt seat' (Post-Courier 24 April 2008, p. 1). It was reported that Waranaka drove a government vehicle to Wamaian village. 'There he saw Paringu. He drove closer to him to converse with him, then moved closer to him and slipped a K50 note into his hand, and said: "Yu holim dispela moni na tingim $m i$ " (you take this money and think of me). He showed the money to others who were there, and then instructed his son, daughter and wife to vote for Wararu' (The National 24 April 2008, p. 1f). Waranaka's election was thus declared null and void, but Waranaka 'told his supporters it was only one allegation of K50 that had ended his election as Member and he would be instructing his lawyers to appeal that decision' (Post-Courier 24 April 2008, p. 8). In March 2009 the Supreme Court, in a unanimous decision, overturned the National Court ruling, arguing that 'the trial judge failed to establish the intent of the $\mathrm{K} 50$ and erred in his judgement' (Post-Courier 6 March 2009), and Waranaka was reinstated as the member for Yangoru-Saussia and provincial governor.

\section{References}

Geno, Ila, 2005. 'Developing Investigative Methods that Work. The Papua New Guinea Experience.' Paper presented at Australasian and Pacific Ombudsman Regional Conference, Wellington.

Gesch, Patrick, 1985. Initiative and Initiation. A Cargo Cult Type Movement in the Sepik against its Background in Traditional Village Religion. Nettetal: Steyler Verlag.

Institute of Policy Studies, Victoria University, New Zealand; Papua New Guinea Institute for National Affairs; and Transparency International (PNG), 2004. The Election Audit Report. Election Lessons Prepared for the PNG Electoral Commission on 3 By-elections held in Papua New Guinea in mid 2004. Wellington: Victoria University. 
Winnett, Bob and May, R.J. 1983. 'Yangoru-Saussia Open: the disappearance of an 83 percent majority', in David Hegarty (ed.), Electoral Politics in Papua New Guinea. Studies on the 1977 National Elections. Port Moresby: University of Papua New Guinea Press, pp. 255-267.

\section{Appendix}

Table 24.1: Voting statistics for Yangoru-Saussia Open electorate, 2007 election

\begin{tabular}{lrl} 
Number of registered voters & 36,861 \\
Total votes cast & 26,406 \\
Informal votes & $74 \quad$ (0.3\% of ballots cast) \\
Total allowable ballot papers & 26,332 \\
Total ballot papers remaining in count & 16,549 \\
Total votes distributed & 14,162 \\
Exhausted ballot papers & $9,783 \quad(37.2 \%$ of allowable ballots $)$ \\
Absolute majority $(50 \%+1)$ & 8,276 \\
\hline
\end{tabular}


24. Organization Takes the Spoils: The Election in Yangoru-Saussia

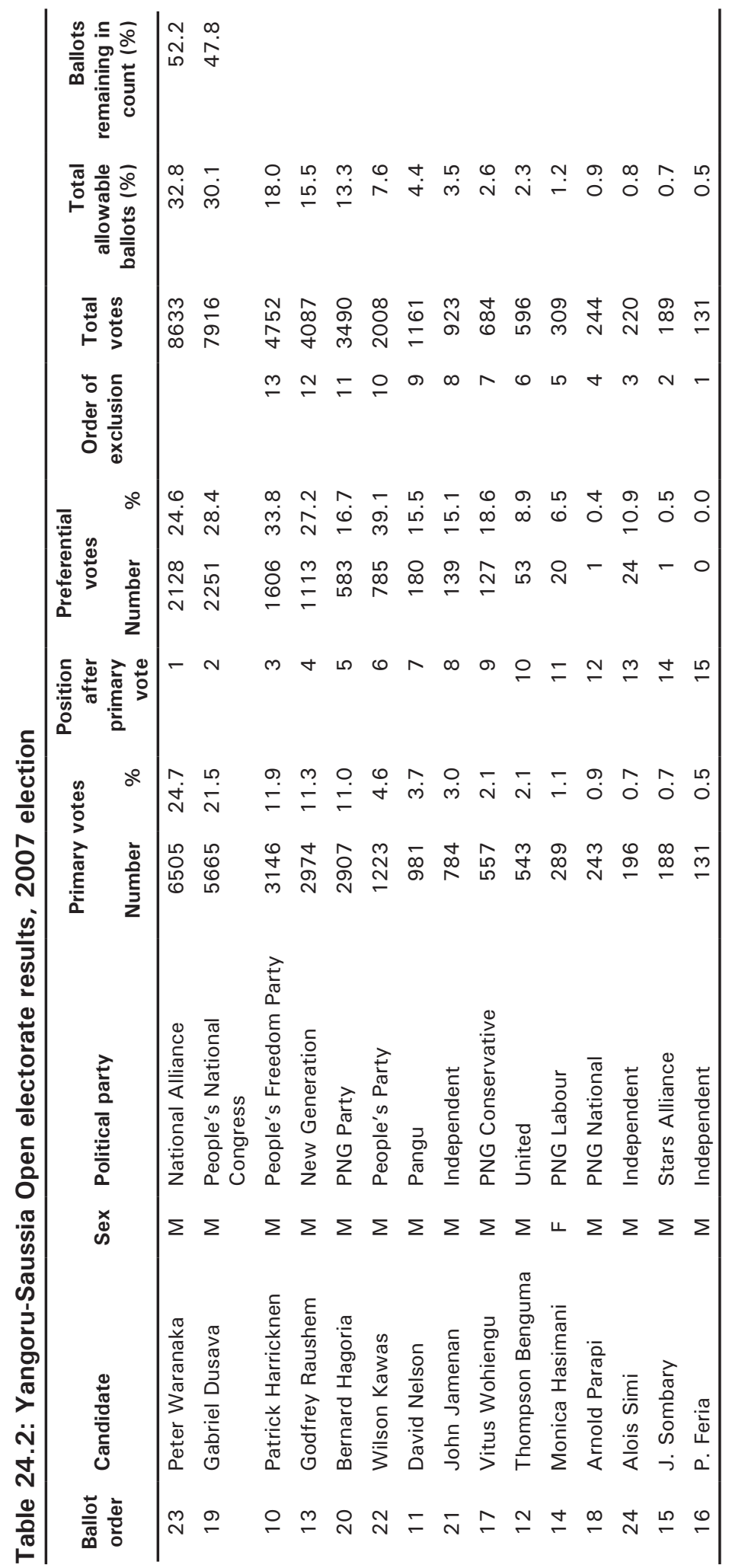

